\title{
ISLAM INKLUSIF: TELAAH ATAS DOKTRIN DAN SEJARAH
}

\author{
Zain Abidin \\ Character Building Development Center, BINUS University \\ Jln. Kemanggisan Ilir III No. 45, Kemanggisan - Palmerah, Jakarta 11480 \\ aby.zie@gmail.com
}

\begin{abstract}
This work is entitled Inclusive Islam: The study of doctrine and history. This study uses hermeneutic approach (hermeneutics approach), and method used in collecting data is library research (library research). This work was motivated by a phenomenon that is now Muslims no longer perform the inclusive theology. Religion expected to bring the mercy mission to the world no longer show its role significantly. This may be due to religious thought has been contaminated by a variety of politic, economic, culture, and so forth. Now religious understanding is necessary to be reconstructed, by putting forward the spirit of togetherness and a mercy to the world. Religious understanding seems to be justified by faith, when in fact it is not; in fact,it conflicts with any religious teachings. Therefore, in this work, the author would like to show an understanding of Islam that is open, flexible, and tolerant (Islam Inclusive). Inclusive Islam is the religious understanding or insight that is open, flexible, and tolerant. Open has a meaning that Islam provides opportunities for people to criticize, if the truth or wisdom is delivered, then a tolerant religious have to accept, though of anyone or anything coming. Flexible means meaningful contact with others, without feeling awkward, and also regardless of the differences that exist, whether religion, creed, or origin. Tolerant means respecting the differences that exist, either with the same religion/belief or with a different religion/belief. Such an understanding is not only shaped by history but the doctrinal background can be found in the major source of the teachings of Islam, namely the Qur'an and the Sunnah of Prophet Muhammad SAW.
\end{abstract}

Keywords: inclusive Islam, inclusive-pluralist, doctrine, history

\begin{abstract}
ABSTRAK
Karya ini berjudul, Islam Inklusif: Telaah atas Doktrin dan Sejarah. Penelitian ini menggunakan pendekatan hermeneutik (hermeneutics approach), dan metode yang digunakan dalam pencarian data adalah penelitian kepustakaan (library research). Karya ini dilatarbelakangi oleh fenomena yang ada saat ini, bahwa bahwa kaum Muslim tidak lagi melaksanakan dengan baik teologi inklusifnya. Agama yang diharapkan membawa misi rahmat bagi seluruh alam tidak lagi menunjukkan peranannya secara signifikan. Hal ini boleh jadi karena paham keagamaan tersebut telah terkontaminasi oleh berbagai kepentingan politik, ekonomi, budaya, dan sebagainya. Kini paham keagamaan dipandang perlu untuk direkonstruksi, dengan mengedepankan semangat kebersamaan dan rahmat bagi seluruh alam. Pemahaman keagamaan seperti itu seakan-akan dibenarkan oleh agama, padahal sebenarnya tidak, bahkan bertentangan dengan setiap ajaran agama. Karena itu, dalam penelitian ditampilkan pemahaman Islam yang terbuka dan toleran (Islam inklusif). Islam inklusif yang dimaksud adalah pemahaman atau wawasan keagamaan yang terbuka, luwes, dan toleran. Terbuka memiliki makna bahwa Islam memberikan peluang kepada manusia untuk mengkritisinya jika kebenaran atau hikmah yang disampaikan tersebut, seorang umat beragama harus berlapang dada untuk menerima, walaupun dari siapa atau apa pun datangnya. Luwes bermakna mau berhubungan dengan pihak lain, tanpa rasa canggung, dan juga tanpa melihat perbedaan yang ada, baik agama, kepercayaan, maupun asal usul. Toleran bermakna menghormati perbedaan yang ada, baik dengan yang seagama atau sekeyakinan maupun dengan yang berbeda agama atau keyakinan. Pemahaman yang demikian tidak hanya dibentuk oleh latar sejarah tetapi secara doktrinal dapat ditemukan dalam sumber ajaran utama Islam yaitu al-Qur'an dan Sunnah Nabi Muhammad SAW.
\end{abstract}

Kata kunci: Islam inklusif, inklusif-pluralis, doktrin, sejarah 


\section{PENDAHULUAN}

Teologi inklusif-pluralis, keberadaannya tentu sudah mengandaikan satu lompatan pemikiran teologis yang lebih terbuka dan moderat, dari sekadar teologi eksklusif. Patut dimaklumi, bahwa teologi selama ini, menurut Sukidi (2001) seperti sudah di-set up dalam kerangka teologi eksklusif, yang menganggap bahwa kebenaran (truth) dan keselamatan (salvation) suatu agama, menjadi monopoli agama tertentu. Sementara pada agama lain, diberlakukan dan bahkan ditetapkan standar lain yang sama sekali berbeda: "salah dan karenanya tersesat di tengah jalan”. Hal ini sudah merusak ke wilayah state of mind, cara pandang suatu komunitas agama (religious community) terhadap agama lain, dengan menggunakan cara pandang agamanya sendiri (teologi eksklusif), tanpa sedikit pun menyisakan ruang toleransi untuk bersimpati, apalagi empati: "bagaimana orang lain memandang agamanya sendiri”.

Seperti sudah taken of granted, kita sering kali menilai dan bahkan menghakimi agama orang lain, dengan memakai standar teologi agama sendiri. Pun sebaliknya, orang lain menilai dan bahkan menghakimi, dengan memakai standar teologi agamanya. Jelas, ini suatu mission impossible untuk bisa saling bertemu, apalagi sekadar toleransi. Hasilnya justru berbalik arah: masing-masing agama malah menyodorkan proposal "klaim kebenaran" (truth claim) dan "klaim keselamatan" (salvation claim) yang hanya "ada" dan "berada” pada agamanya sendiri-sendiri. Sementara pada agama lain dituduh "salah, menyimpang, dan bahkan menyesatkan”.

Sejalan dengan kesadaran inklusifisme dan pluralisme (Sunardi dalam Dian, 1994: 69), cara berpikir agama yang ditandai oleh klaim kebenaran (truth claim) dan klaim keselamatan (salvation claim) dipandang tidak lagi memadai untuk mempertanggungjawabkan kenyataan akan keanekaragaman agama (Munawar-Rahman, 2001). Karena itu diharapkan penerimaan bahwa semua agama setara: sama-sama mengandung kebenaran dan merupakan jalan keselamatan, atau paling tidak memandang bahwa dalam agama lain pun ada jalan kebenaran dan keselamatan juga. Selain itu, dari pengalaman manusia belajar arif bahwa sebagai realitas kultural historis tidak ada agama yang sepenuhnya benar dan tidak ada juga yang sepenuhnya sesat. Karena itu sikap yang paling bijaksana dalam merespons pluralitas agama adalah dengan mengembangkan teologi inklusif.

Dalam konteks kaum Muslim, teologi Islam yang dibangun sebenarnya bersifat inklusif bahkan plural. Teologi inklusif yang dikandung dalam ajaran Islam menganut prinsip-prinsip moderat. Penegakkan kebenaran harusnya dilakukan dengan jalan kebenaran pula, bukan dengan jalan kekerasan. Kemauan untuk menghormati agama lain adalah perwujudan dari sikap moderat. Sikap moderat seperti ini tidak berarti bahwa kita tidak konsisten terhadap agama, melainkan penghormatan akan seseorang. Semangat inklusif memiliki semangat mencari kebenaran dan mendialogkannya. Pantang menggunakan kekerasan dalam menegakkan kebenaran. Lebih bersikap terbuka ketimbang keras kepala, baik dalam menerima kebenaran yang ada dalam agama non-Islam, maupun bersamasama membangun masyarakat yang menjunjung tinggi nilai-nilai kemanusiaan.

Teologi Islam yang inklusif adalah rahmatan lil alamin (rahmat bagi seluruh alam) teologi tersebut adalah pilar moderatisme Islam. Di sini, ajaran Islam tidak diarahkan kepada eksklusivisme seperti membenci agama lain, merendahkan non-muslim, atau memusuhi dan menggunakan kekerasan dalam menyiarkan kebenaran, bahkan Islam inklusif menyiarkan toleransi beragama dan juga kerja sama. Perbedaan agama tidak menjadi penghalang untuk berinteraksi dan aksi. Sejak awal Islam selalu menganjurkan untuk merangkul non-muslim bekerja sama membangun masyarakat, maka dengan sendirinya Islam mempromosikan perdamaian bukan kekerasan.

Namun dalam praktik kekinian, kita dihadapakan pada kenyataan bahwa kaum Muslim tidak lagi melaksanakan dengan baik teologi inklusifnya. Agama yang diharapkan membawa misi rahmat 
bagi seluruh alam tidak lagi menunjukkan peranannya secara signifikan. Hal ini boleh jadi karena paham keagamaan tersebut telah terkontaminasi oleh berbagai kepentingan politik, ekonomi, budaya dan sebagainya. Kini paham keagamaan dipandang perlu untuk direkonstruksi, dengan mengedepankan semangat kebersamaan dan rahmat bagi seluruh alam.

Karena itu, dalam artikel ini penulis ingin melihat dan menganalisis tentang Islam Inklusif: Telaah atas Doktrin dan Sejarah. Ada beberapa hal yang perlu dipahami di sini, yaitu: 1) tentang hal yang dimaksud dengan Islam inklusif tersebut, 2) tentang doktrin, konsep, dan gagasan Islam inklusif, dan 3) tentang sejarah dan perkembangan Islam Inklusif.

\section{DISKUSI DAN PEMBAHASAN}

\section{Islam Inklusif}

Ada tiga istilah yang menjadi perhatian utama dalam pembahasan ini, yaitu: Islam, Inklusif, dan Islam Inklusif. Ketiga istilah tersebut akan dijelaskan secara terperinci agar didapatkan pemahaman yang baik dan benar.

\section{Islam (al-Islam)}

Ada dua katagori yang dapat dipergunakan untuk memahami pengertian islam, yaitu secara etimologis (kebahasaan) dan terminologis (istilah). Secara etimologis kata islam berasal dari kata aslama, yuslimu, islaman (bahasa Arab), yang memiliki beberapa makna, diantaranya adalah : pertama, melepaskan diri dari segala penyakit lahir dan batin, kedua, kedamaian dan keamanan, ketiga, menyerahkan diri, ketundukan, ketaatan, dan kepatuhan, dan keempat, memohon selamat dan sentosa. Kata islam tersebut berasal dari salima yang berarti selamat, sentosa, aman dan damai (Dewan RedaksI EnsIklopedI Islam, 1994; Nata, 2000; Madjid, 1995; Hidayat, 1990). Selanjutnya orang yang memiliki sifat-sifat tersebut disebut sebagai muslim atau muslimat, namun biasanya sebutan tersebut dikhususkan bagi mereka yang telah mengimani dan memeluk Islam yang diwahyukan kepada Nabi Muhammad SAW.

Secara etimologis, kata islam maknanya dekat dengan kata din, yang berarti menguasai, menundukkan, patuh, hutang, balasan, dan kebiasaan (Nasution, 1985). Biasanya dalam bahasa Indonesia kata din diartikan agama (Nasution, 1985; Suma, 2001) dan dalam bahasa Inggris diistilahkan dengan kata religi (Nasution, 1985:10) padahal makna masing-masing berbeda dengan makna din. Kedekatan makna tersebut karena: keduanya, baik islam maupun din membawa peraturanperaturan yang harus dipatuhi. Keduanya menguasai diri manusia dan membuatnya tunduk kepada Tuhan dengan menjalankan ajaran-ajaran agama. Keduanya membawa kewajiban-kewajiban yang kalau tidak dilaksanakan menjadi hutang bagi yang bersangkutan. Paham kewajiban dan kepatuhan islam maupun din membawa pula kepada paham balasan. Yang menjalankan dan patuh kepada islam maupun din akan mendapat balasan baik dari Tuhan dan begitu juga sebaliknya.

Dari uraian tersebut, dapat disimpulkan bahwa secara etimologis kata islam yang paling tepat adalah apa yang dikatakan oleh Ali bin Abi Thalib, saudara dan sekaligus menantu Nabi Muhammad SAW, yaitu al-islam huwa al-taslim, islam ialah penyerahan diri (Abi Thalib, 1991), dan beberapa arti yang terdapat pada nomor tiga, yaitu menyerahkan diri, ketundukan, ketaatan, dan kepatuhan. Madjid (1992) menjelaskan, bahwa sikap tersebut merupakan hakikat pengertian islam (Madjid, 1992). Hal ini sesuai dengan fitrah manusia sebagai makhluk yang beragama, al-Qur’an menjelaskan: 


\begin{abstract}
"Maka hadapkanlah wajahmu dengan lurus kepada agama (Allah); (tetaplah atas) fitrah Allah yang telah menciptakan manusia atas fitrah itu. Tidak ada perubahan atas fitrah Allah. Itulah agama yang lurus, tatapi kebanyakan manusia tidak mengetahui.” (QS al-Rum/30: 30).
\end{abstract}

Yang dimaksud fitrah tersebut adalah islam yaitu menyerahkan diri, ketundukan, ketaatan, dan kepatuhan. Sikap tersebut bukan saja merupakan ajaran Tuhan kepada hamba-hamba-Nya, tetapi ia diajarkan oleh-Nya dengan dihubungkan kepada alam manusia itu sendiri. Dengan kata lain, ia juga diajarkan sebagai pemenuhan alam manusia, sehingga pertumbuhan perwujudannya pada manusia selalu bersifat dari dalam, tidak tumbuh, apalagi dipaksakan dari luar, karena cara yang demikian menyebabkan islam tidak autentik, karena kehilangan dimensinya yang paling mendasar dan mendalam, yaitu kemurnian dan keikhlasan. Karena Tuhan telah menganugrahkan fitrah tersebut, maka manusia pun dapat kembali memahaminya. Sehubungan dengan hal tersebut, Haji Abdul Malik Karim Amarullah (Buya Hamka), menjelaskan :

\begin{abstract}
"Sebab itu maka agama manusia yang mula-mula itulah agama fithrah. Setelah manusia menerawang, berfikir, merenung, membanding, mengukur, menjangka, pendeknya memfilosofi, akhirnya sampailah dia diujung perjalanan. Di dinding yang tak tersebrangi itu. Segala macam telah dicobanya. Akhirnya yakinlah dia memang ada sesuatu itu. Dialah Yang Maha Mutlak, Dialah Yang Maha Kuasa, Dialah puncak dari puncaknya ideal (kata Plato). Dialah Tao yang tak dapat diberi nama (kata Lao Tze). Maka insyaflah manusia akan kelemahan dirinya, dan insyaf akan Maha Besarnya Yang Ada itu. Maka menyerahlah dia dengan rela hati. Penyerahan yang demikian dalam bahasa Arab dinamai islam.” (Hamka, 1989).
\end{abstract}

Selain itu, sikap islam tersebut, tidak hanya ada pada manusia, tetapi dimiliki juga oleh segala sesuatu, bahkan ia pun ada sejak alam ini diciptakan oleh Tuhan. Ali menambahkan bahwa ketundukkan dan kepatuhan segala sesuatu kepada undang-undang Allah tersebut secara tak sadar dapat disaksikan di alam semesta ini (Ali, 1980). Tidak jauh berbeda dengan Ali, Taha, seorang intelektual Muslim asal Sudan, menjelaskan bahwa islam adalah sebuah kehidupan praktis, sikap, dan prilaku, cara atau petunjuk; hal ini berarti bahwa Allah menunjukkan kepada makhluk-Nya untuk patuh dan tunduk, yang merupakan esensi dari segala sesuatu (Taha, 1996). Penyerahan diri, ketundukan, ketaatan, dan kepatuhan, secara tulus ikhlas kepada Tuhan Pencipta semesta, itulah islam sejati yang merupakan esensi dari setiap agama yang diajarkan oleh para nabi dan rasul, begitu juga Islam yang diajarkan oleh Nabi Muhammad SAW.

Adapun pengertian islam secara terminologis dapat dilihat dari definisi-definisi yang dikemukakan oleh beberapa tokoh. Hamka, misalnya, memberikan pengertian islam sebagai agama yang diwahyukan oleh Tuhan kepada Nabi Muhammad SAW dengan perantaraan Malaikat Jibril, termaktub di dalam Kitab Suci al-Qur'an dan ditafsirkan oleh Sunnah Nabi Muhammad SAW (Hamka,1986). Tidak berbeda dengan Hamka, Nasution (1985) mendefinisikan islam sebagai agama yang ajaran-ajarannya diwahyukan oleh Tuhan kepada masyarakat manusia melalui Nabi Muhammad s.a.w. sebagai rasul.

Selain kedua tokoh tersebut, Sjadzali (menyorotinya dari fungsi Islam) menjelaskan bahwa islam yang dibawa oleh nabi besar Muhammad SAW dulu adalah betul-betul rahmatan li al- 'alamin (kasih sayang bagi semesta); pemberi petunjuk kepada mereka yang sesat jalan (yang memuja bendabenda hasil karya tangan mereka sendiri), penegak keadilan, pembela mereka yang lemah, pelopor peningkatan martabat kaum wanita, pemberi perdamaian kepada mereka yang selama ini saling bermusuhan, dan pendorong pencarian kebenaran lewat peningkatan ilmu pengetahuan (Sjadzali, 1997).

Selanjutnya Rahman, berdasarkan QS al-Zumar/39: 22 dan al-Maidah/5: 125 menjelaskan bahwa islam memiliki pengertian baik "menyerah kepada hukum Tuhan” maupun agama formal yang disebut islam, meskipun nama ini tidak diberikan secara formal hingga periode Madinah (dalam Kamal 1993). Sedangkan Yahudi dan Nashrani tidak lagi masuk dalam katagori islam ataupun hanif, 
karena mereka tidak lagi memiliki kepercayaan monoteisme sebagaimana nabi-nabi sebelumnya. Mereka telah mendistorsikan ajaran-ajaran asli, dan mudah terjerumus dalam perbuatan syirik (Kamal 1993: 100).

Selain para tokoh tersebut, Taha mendefinisikan islam agak unik dan sedikit berbeda dengan tokoh-tokoh yang lain, yaitu suatu proses intelektual seorang hamba berproses dalam penghambaannya di suatu jenjang yang terdiri dari tujuh tahapan, yaitu al-islam, al-iman, al-ihsan, 'ilm al-yaqin, 'ilm 'ain al-yaqin, 'ilm haqq al-yaqin, dan al-islam. Pada tahap awal, al-islam hanyalah kepatuhan eksternal atau yang nampak luarnya saja, yang berhubungan dengan ucapan dan tindakan, sementara al-islam pada tahapan akhir merupakan penyerahan dan kepatuhan intelegensia serta penerimaan atas Allah, baik secara pribadi maupun umum, dan merupakan kepatuhan eksternal dan internal sekaligus (Taha, 1996). Inilah islam yang diajarkan oleh Nabi Muhammad SAW, sebagai penyempurna ajaran-ajaran sebelumnya, tegas Taha (1996).

Dari berbagai pengertian tersebut, maka pengertian islam menurut istilah mengacu kepada agama yang bersumber dari wahyu Allah SWT yang disampaikan kepada Nabi Muhammad SAW dengan tujuan untuk kesejahteraan dan kebahagiaan hidup umat manusia di dunia dan akhirat (islam dalam pengertian ini mempergunakan huruf kapital I [Islam]).

Untuk keperluan tulisan ini, penulis mempergunakan kata Islam dalam tiga tataran makna yang saling terkait, yaitu: Pertama, Islam sebagai sebuah agama yang memberikan sebuah kredo, seperangkat doktrin, suatu ritus praktis ibadah, dan sikap moral spitual. Kedua, Islam sebagai sebuah fenomena historis yang memberikan identitas kultural nasional dan rasa keberagamaan lintas kebangsaan bagi para pengikutnya. Ketiga, Islam sebagai suatu kekuatan peradaban yang terus membentuk respons kaum Muslim terhadap realitas sosial politik dan terhadap konteks-konteks masa kini, sehingga kaum Muslim dapat terus beradaptasi dalam suatu masyarakat global yang beragam.

\section{Inklusif}

Kata inklusif berasal dari bahasa Inggris, inclusive yang berarti sampai dengan atau termasuk (Echols \& Shadily, 1996:316). Istilah ini digunakan untuk menunjukkan pada suatu keadaan atau sikap yang memandang kelompok lain sebagai bagian atau termasuk dari keadaan tersebut. Selain itu istilah ini juga digunakan untuk menyatakan bahwa sesuatu yang dimiliki seseorang boleh jadi juga terdapat pada orang lain, atau kebenaran yang dimiliki oleh suatu agama, boleh jadi terdapat juga dalam agama yang lain.

Jadi inti dari inklusif ialah keinginan untuk saling mengerti, saling memahami, dan saling memberi antara satu kelompok dengan kelompok lainnya. Seorang inklusifis tidak membiarkan dirinya untuk didominasi atau diperbudak oleh satu paham, ajaran, kepercayaan maupun agama. Baginya, klaim kebenaran (claim of truth) dan klaim keselamatan (claim of salvation) bukan monopoli kelompok atau agama tertentu, tetapi juga ada pada kelompok atau agama lain. Sangat tepat yang diungkapkan oleh Smith, bahwa kedua klaim tersebut sebenarnya sama saja dengan mengatakan bahwa Tuhan hanya ditemukan dalam ruangan ini saja dan tidak ada dalam ruangan sebelah atau hanya dalam busana ini saja, dan tidak ada dalam busana lain (Smith, 2005).

Paradigma inklusif tersebut pertama kali dimunculkan oleh Karl Rahner, dengan istilah Kristen anonim (the Anonimous Christian), yaitu orang-orang non-Kristiani. Para "Kristen anonim" ini dalam pandangan Rehner sebagaimana dikutip oleh Munawar-Rahman, juga akan selamat, sejauh mereka hidup dalam ketulusan hati kepada Tuhan, karena karya Tuhan ada pada mereka, walaupun mereka belum pernah mendengar Kabar Baik (Munawar-Rachman, 2001). Alan Rece, the Anglican Chaplain pada Universitas Kent, menjelaskan bahwa paradigma inklusif membedakan antara kehadiran penyelamatan (the salvafic presence) dan aktivitas Tuhan dalam tradisi agama-agama lain, dengan penyelamatan dan aktivitas Tuhan sepenuhnya dalam Yesus Kristus. Lebih lanjut dikatakan: 
"Menjadi inklusif berarti percaya bahwa seluruh kebenaran agama non-Kristiani mengacu pada Kristus..." (Munawar-Rachman, dalam Kartika dan Mahendra, 1999:142). Inklusivisme agama tidak melepaskan keyakinan bahwa yang benar adalah agama sendiri. Jadi bagi orang Kristen, hanyalah karena manusia Yesus dari Nazaret segenap orang akan selamat. Inklusivisme tidak mengakui semua agama lain sama-sama benar, tetapi disebut inklusivisme karena mereka menerima bahwa orang dari agama-agama lain juga dapat selamat (Suseno, dalam Sudiarja dan Laksana, 2003). Dan di sinilah, posisi Konsili Vatikan II, demikian komentar Suseno.

Tidak berbeda dengan tokoh-tokoh tersebut, Madjid mendefinisikan inklusivisme sebagai paham keagamaan yang mempelajari dan memahami paham, ajaran, kepercayaan ataupun agama yang lain, sehingga tidak ada monopoli surga atau neraka. Masing-masing mengklaim kebenaran sendiri, menurutnya itu namanya thugyan al-fikr (menipu pemikiran): thaghut dalam soal pikiran, tirani pikiran. Intinya adalah toleransi, tidak ada paksaan dalam agama, dikaitkan dengan perlawanan kepada tirani pikiran (Madjid, dalam Sukidi, 2001). Sementara Alwi Shihab mendefinisikan inklusivisme sebagai paham keagamaan yang mengakui eksistensi orang-orang yang berbuat kebaikan dalam setiap komunitas beragama, dan dengan begitu, layak memperoleh pahala dari Tuhan (Shihab, 1998). Senada dengan Shihab, Nata mengartikannya sebagai suatu paham keberagamaan yang didasarkan pada pandangan bahwa agama-agama lain yang ada di dunia ini mengandung kebenaran dan dapat memberikan manfaat dan keselamatan bagi para pemeluknya (Nata, 2001).

Inklusivisme yang dimaksudkan adalah teologi. Teologi inklusif menurut Azyumardi Azra dapat pula disebut teologi kerukunan keagamaan (Azra, 1999). Kerukunan ini baik dalam satu agama tertentu maupun antara satu agama dengan yang lainnya. Tema sentral dari teologi inklusif adalah pengembangan paham dan kehidupan keagamaan yang memperlihatkan keluwesan, toleran, dan respek terhadap pluralisme keagamaan, sehingga para penganut berbagai aliran keagamaan atau agama-agama dapat hidup berdampingan secara damai (paeceful co-exixtence). Penulis memahami inklusivisme tidak hanya menyangkut hubungan satu agama dengan agama lainnya. Lebih dari itu inklusivisme harus dipahami: sebagai cara pandang positif terhadap pluralitas kehidupan manusia, dengan mengedepankan sikap-sikap luwes, toleran, terbuka, dan mau menerima kebenaran lain selain kebenarannya sendiri.

\section{Islam Inklusif}

Adapaun yang dimaksud dengan Islam Inklusif adalah pemahaman atau wawasan keislaman yang terbuka, luwes, dan toleran. Dalam bahasa Gaber Asfour diistilahkan dengan Islam Sungai (Gaber Asfour dalam Umat, September 1999). Pemahaman yang demikian bertolak dari nilai-nilai dasar Islam, dengan ide yang utama "Islam sebagai ajaran kasih sayang untuk dunia" (rahmatan li al'alamin). Ada kriteria tertentu yang menjadi indikator pemahaman Islam Inklusif, sehingga di sini terlihat jelas dasar pemikirannya, serta arah dan tujuannya, di antaranya adalah:

Pertama, Islam Inklusif lebih menekankan kepada nilai-nilai dasar Islam bukan kepada simbol-simbol belaka. menekankan elemen-elemen yang lazim dalam keimanan masing-masing orang khususnya tentang ruhani yang menuju Yang Maha Tinggi, sedangkan ekspresi keimanan yang bersifat lahiriah dalam hukum-hukum agama, ritus, dan doktrin ketuhanan, tidak dipandang sebagai hal yang paling penting. Matori Abdul Jalil menambahkan, implikasinya adalah keberanian untuk membongkar selubung kusam berupa dunia penghayatan Islam yang bercorak doktrinal dan dogmatis (Jalil, dalam Marzuki Wahid, dkk, 1999). Islam tidak hanya ditafsirkan lewat penekanan yang berlebihan atau keterjebakan terhadap simbol-simbol keagamaan justru mengandung bahaya, kontraksi, distorsi, dan reduksi ajaran agama itu sendiri, semangat penekanan terhadap simbol-simbol agama tersebut sering sekali tidak sesuai dengan substansi ajaran agama itu sendiri.

Kedua, menghendaki interpretasi non ortodoks terhadap Kitab Suci al-Qur'an dan dogma Islam, agar jalan keselamatan tersedia juga melalui agama selain Islam. Meskipun teks al-Qur'an 
tuntas diturunkan sebelum wafatnya Nabi Muhammad s.a.w., namun ketiadaan satu-satunya otoritas mufassir membuat tidak sahihnya segala klaim yang mengatakan bahwa dia telah mencapai pemahaman al-Qur'an yang paling benar. Dengan berkembangnya masyarakat Islam dan semakin besarnya persyaratan moral dan legal, karya-karya intelektual yang dihasilkan legal Islam diubah oleh kebutuhan yang terus membesar untuk mencari konteks histories wahyu dalam rangka mendapatkan aturan-aturan praktis bagi ditelurkannya keputusan-keputusan hukum.

Ketiga, skeptis terhadap argumentasi rasional demi kepentingan superioritas keyakinan Islam. Para inklusifis Islam meyakini benar bahwa secara konsep Islam lah yang terbaik dan paling sempurna sebagaimana dinyatakan oleh al-Qur'an: "... Pada hari ini, telah Ku-sempurnakan untuk kamu agamamu, dan telah Ku-cukupkan kepadamu nikmat-Ku ...." (QS al-Ma'idah/5: 3). Namun hal itu tidak cukup, kesempurnaan Islam tersebut harus dibuktikan lewat karya nyata dari kaum Muslim itu sendiri. Karya tersebut tercermin dalam aneka ragam kebaikan, karena itu inklusifis Islam sejati selalu menciptakan aneka ragam kebaikan, fastabiqu al-khairat, berlomba-lombalah kalian semua dalam kebaikan. Dan merekapun tak segan-segan untuk memuji, membanggakan, bahkan meniru kebaikankebaikan yang datang dari pihak lain.

Keempat, menganjurkan prinsip-prinsip dialog, toleransi, dan menolak prasangka. Para inklusifis Islam meyakini bahwa kebaikan itu tidak hanya dimiliki oleh Islam dan kaum Muslim, tetapi umat-umat yang lain pun memiliki nilai-nilai kebaikan, karena itu sebelum memutuskan benar atau salah terhadap pihak lain terlebih dahulu melakukan dialog dengan mereka, sehingga tercipta kehidupan yang penuh toleransi dan terhindar dari prasangka-prasangka buruk.

Kelima, menganjurkan prinsip-prinsip moral modern tentang domokratisasi, hak azasi manusia, persamaan kedudukan dalam hukum, dan lainnya. Kemajuan zaman telah "memaksa" para inklusifis Islam untuk mempelajari wawasan-wawasan baru dan menyesuaikannya dengan prinsipprinsip Islam, baik yang bersumber dari al-Qur'an, Hadits Nabi Muhammad s.a.w., maupun karyakarya para intelektual Muslim.

\section{Doktrin, Konsep, dan Gagasan Islam Inklusif}

Sebagaimana agama-agama lainnya Islam juga mengandung klaim-klaim keeksklusifan, bahkan menurut Azyumardi Azra keeksklusifan Islam itu, dalam segi-segi tertentu bisa sangat ketat (Azra, 2001). Hal ini terlihat jelas, misalnya, dalam dua kalimat syahadat yang merupakan kesaksian dan pengakuan terhadap Kemahamutlakan Tuhan dan sekaligus keabsahan kerasulan Muhammad. Lebih tegas lagi, Sayyid Husein Nasr menyatakan, "Keeksklusifan suatu agama adalah perlambang dari kenyataan bahwa ia berasal dari Yang Mutlak, perlambang dari wujudnya sendiri sebagai suatu cara hidup yang menyeluruh” (Nasr, 2000:178).

Di samping klaim-klaim eksklusif tersebut, Islam juga memberikan penekanan khusus pada inklusivisme keagamaan. Adapun menganai asal-usulnya dapat dilihat dari sumber ajaran suci Islam yaitu al-Qur'an al-Karim dan beberapa Hadits Nabi Muhammad S.A.W. Ada beberapa tema yang penyusun pandang sangat urgen untuk membuktikan wawasan Islam Inklusif, di antaranya adalah:

\section{Tidak Ada Paksaan dalam Beragama}

Sebagaimana diketahui, Kitab Suci al-Qur'an mengajarkan prinsip bahwa semua orang dilahirkan dalam keadaan fithrah, begitu pula dengan keyakinan agama. Al-Qur'an menjelaskan: "Maka hadapkanlah wajahmu dengan lurus kepada agama (Allah); (tetaplah atas) fitrah Allah yang telah menciptakan manusia atas ftrah itu. Tidak ada perubahan atas fitrah Allah. (Itulah) agama yang lurus, tetapi kebanyakan manusia tidak mengetahui." (QS al-Rum/30: 30). Menurut Quraish Shihab, fithrah adalah sesuatu yang melekat pada diri manusia dan terbawa sejak kelahiranya (Shihab, 1998). 
Ini berarti bahwa manusia tidak dapat melepaskan diri dari agama. Tuhan menciptakan demikian, karena agama merupakan kebutuhan hidupnya. Atas dasar prinsip ini, Islam menegaskan prinsip bahwa setiap manusia adalah homo religious (Azra, 2001).

Dengan fitrahnya setiap manusia dianugerahi kemampuan dan kecenderungan untuk mencari, mempertimbangkan, dan memahami kebenaran, yang pada gilirannya akan membuatnya mampu mengakui Tuhan sebagai sumber Kebenaran tersebut. Pencarian akan Kebenaran yang tulus dan murni akan mustahil jika dilakukan dalam semangat komunal dan sektarian. Ia harus bebas dari setiap kemungkinan pengungkungan rohani. Kemampuan dan kecenderungan tersebut disebut sebagai sikap hanif (sebagaimana QS al-Rum/30: 30). Di dalam al-Qur'an, manusia hanif diidentifikasikan dengan Nabi Ibrahim A. S., yang dikenal sebagai panutan tiga agama wahyu, yaitu Yahudi, Kristen, dan Islam, dan dalam kalangan ahli perbandingan agama disebut sebagai agama Abrahamik (Abrahamic religions).

Karena keyakinan agama merupakan hasil pencarian dan perenungan setiap individu, Islam tidak membenaran setiap konsep, gagasan atau tindakan yang mengarah kepada pemaksaan suatu agama atau kepercayaan, al-Qur’an menjelaskan:

"Tidak ada paksaan untuk (memasuki) agama (Islam); sesungguhnya telah jelas jalan yang benar daripada jalan yang sesat....” (QS al-Baqarah/2: 256)

Secara eksplisit al-Qur'an mengajarkan bahwa dalam hal agama atau kepercayaan, manusia diberi kebebasan untuk mengetahui, memahami, dan mempertimbangkannya sendiri. Keistimewaan tersebut diberikan kepada manusia, karena manusia memiliki yang istimewa pula, yang oleh Madjid diistilahkan dengan "sesuatu dari Ruh Tuhan", sehingga manusia mempunyai kesadaran penuh dan kemampuan untuk memilih. Dalam memahami hal ini, Thabathaba'i menjelaskan bahwa karena agama merupakan rangkaian 'ilmiyyah (pengetahuan) yang diikuti oleh 'amaliyyah (perwujudan perilaku) dan menjadi kesatuan i'tiqadiyyah (keyakinan) yang merupakan persoalan hati, bagaimanapun agama tidak dapat dipaksakan oleh siapapun (Usman, 2002).

\section{Pengakuan Eksistensi Agama Lain}

Jika Islam menolak pemaksaan agama, bagaimana halnya dengan dakwah Islam? Islam tentu saja mewajibkan kepada para penganutnya untuk menyampaikan pesan-pesan Islam melalui dakwah, panggilan kepada kebenaran dalam Islam (QS al-Nahl/16: 125, al-Hajj/22: 67, dan Fushshilat/41: 33). Al-Qur'an menegaskan: "Serulah (manusia) kepada jalan Tuhanmu dengan hikmah, peljaran yang baik, dan banahlah mereka dengan cara yang baik (pula) ...", (QS al-Nahl/16: 125). "... Dan serulah kepada (agama) Tuhanmu ...", (QS al-Hajj/22: 67). "Siapakan yang lebih baik perkataannya daripada orang yang menyeru kepada Allah ...", (QS Fushshilat/41: 33). Karena dakwah merupakan "panggilan”, konsekuensinya adalah bahwa dakwah tersebut harus tidak dengan pemaksaan.

Dengan demikian, Islam mengakui hak hidup agama-agama lain; dan membenarkan para pemeluk agama lain tersebut untuk menjalankan ajaran agama masing-masung. Di sinilah letaknya keinklusifan Islam. Kitab Suci al-Qur'an menjelaskan seperti dalam QS al-Baqarah/2: 62 dan alMaidah/6: 69 - walaupun tafsirnya masih diperdebatkan - menjamin keselamatan para pemeluk agama lain, bahkan kedua ayat ini dijadikan sebagai dasar pemikiran Islam inklusif.

"Sesungguhnya orang-orang yang beriman, orang-orang Yahudi, Nashrani, dan Shabi'in, siapa saja yang beriman kepada Allah, Hari Kemudian, dan beramal shaleh, mereka akan menerima pahala dari Tuhan mereka, tidak ada kekhawatiran atas mereka dan tidak pula mereka bersedih hati.” (QS al-Baqarah/2: 62) 
"Sesungguhnya orang-orang yang beriman, orang-orang Yahudi, Shabi'in, dan Nashrani, siapa saja yang beriman kepada Allah, Hari Akhir, dan beramal shaleh, maka tidak ada kekhawatiran atas mereka dan tidak pula mereka bersedih hati.” (QS al-Ma'idah/5: 69)

Pengakuan Allah terhadap eksistensi agama-agama lain, dengan tidak membedakan kelompok, ras, suku atau bangsa sangatlah jelas. Namun sangat disayangkan mayoritas mufassir Muslim dengan sia-sia telah berusaha untuk tidak menerima maksud yang jelas sekali dinyatakan oleh kedua ayat tersebut, bahwa orang-orang - dari kaum yang manapun juga - yang mempercayai Allah, Hari Akhir, dan melakukan amal-kebaikan akan memperoleh keselamatan. Para mufassir Muslim tersebut mengatakan bahwa yang dimaksud dengan orang-orang Yahudi, Kristen, dan Shabi'in dalam kedua ayat tersebut adalah mereka yang telah masuk Islam. Penafsiran seperti ini jelas salah, komentar Fazlur Rahman, karena seperti yang terlihat dalam ayat tersebut, orang-orang Muslim adalah yang pertama di antara empat kelompok "orang-orang yang percaya kepada ..." (Rahman, 1983:239). Selanjutnya komentar-komentar tersebut mengatakan bahwa mungkin pula bahwa yang dimaksud dengan orang-orang Yahudi, Kristen, dan Shabi'in itu adalah mereka yang saleh sebelum kedatangan Nabi Muhammad S. A. W., inilah penafsiran yang lebih salah, tegas Rahman (1983). Selanjutnya terhadap pernyataan orang-orang Yahudi dan Kristen bahwa di akhirat nanti mereka saja yang akan memperoleh keselamatan al-Qur'an berkata:

"(Tidak demikian) bahkan barangsiapa yang menyerahkan diri kepada Allah, sedang dia berbuat kebajikan, maka baginya pahala pada sisi Tuhannya dan tidak ada kekhawatiran terhadap mereka dan tidak (pula) mereka bersedih.” (QS al-Baqarah/2: 112)

Maka yang perlu digarisbawahi bahwa justru aktivitas umat beragama harus ada dalam katagori penyerahan diri mereka hanya terhadap Tuhan Yang Maha Esa dan amal soleh. Berarti pula bahwa para pemeluk agama-agama yang bersangkutan tersebut ditantang pula untuk senantiasa berlomba-lomba menciptakan kebaikan-kebaikan dalam bentuknya yang nyata, yang disemangati oleh penyerahan diri mereka hanya kepada Tuhan Yang Maha Esa.

\section{Kesatuan Kenabian}

Islam mengajarkan pada kaum Muslim agar beriman kepada para nabi dan rasul, tidak hanya kepada Muhammad S. A. W., tetapi juga kepada yang lainnya sejak yang pertama hingga yang akhir. Keimanan tersebut tidak hanya terbatas pada mereka yang disebutkan oleh al-Qur'an atau hadits Nabi Muhammad S.A.W., tetapi juga mereka yang tidak disebutkan. Keimanan kepada mereka sekaligus mengandung arti untuk tidak membeda-bedakan mereka, "Kami (Allah) tidak membeda-bedakan seorang pun di antara mereka...” (QS al-Baqarah/2: 156). Karena pada dasarnya mereka juga adalah hamba pilihan Allah yang mendapat tugas kepada suatu kaum agar mereka berserah diri kepada Allah SWT semata.

Dalam al-Qur'an dikatakan bahwa para nabi dan rasul menyeru kaum-kaum dan bangsabangsa yang berbeda pada masa-masa yang berbeda pula, tetapi risalah-risalah yang disampaikan oleh mereka adalah universal dan identik. Semua risalah tersebut menurut Fazlur Rahman terpancar dari sebuah sumber yang tunggal (Rahman, 1983): Um al-Kitab, Ibu Semua Kitab (QS al-Ra'd/13: 39 dan al-Zukhruf/43:4) atau Kitabun Maknun, Kitab yang Terpelihara” (QS al-Waqi'ah/56: 78). Dan perkataan "al-Kitab” yang sering dipergunakan oleh al-Qur'an, menurut Fazlur Rahman, bukan dengan pengertian Kitab Suci tertentu tetapi sebagai sebuah istilah umum (generic) dengan pengertian, keseluruhan wahyu-wahyu Allah (Rahman, 1983) seperti dalam QS al-Baqarah/ 2: 213.

Karena risalah-risalah tersebut universal dan identik, maka manusia harus memercayai semuanya. Itulah sebabnya Nabi Muhammad S.A.W. merasa berkeharusan untuk mengakui kenabian Nuh A.S., Ibrahim A. S., Musa A. S., dan Isa A.S. karena agama Allah tidak dapat dipecah-pecah dan demikian pula halnya dengan kenabian. Al-Qur'an menjelaskan: 
"Dia telah mensyariatkan bagi kamu tentang agama, apa yang telah diwasiatkan-Nya kepada Nuh, dan apa yang telah Kami wahyukan kepadamu, dan apa yang telah Kami wasiatkan kepada Ibrahim, Musa, dan Isa, yaitu tegakkanlah agama dan janganlah kamu berpecah belah tentangnya...." (QS al-Syura'/42: 13).

Al-Qur'an menyuruh Muhammad untuk mengatakan bahwa di samping memercayai Taurat dan Injil, juga diperintahkan untuk mempercayai setiap kitab yang diwahyukan oleh Allah; “... Aku beriman kepada semua kitab yang diturunkan oleh Allah ...” (QS al-Syura'/42:15). Hal ini karena petunjuk Allah adalah universal dan tidak terbatas kepada suatu kaum atau kaum-kaum tertentu saja : “... Dan tidak ada suatu umat pun melainkan telah ada padanya seseorang pemberi peringatan”, (QS Fathir/35:24). "Dan bagi tiap-tiap kaum ada orang yang memberi petunjuk", (QS al-Ra'd/13: 7). "Dan sesunggunya Kami telah mengutus rasul pada tiap-tiap umat (untuk menyerukan); "Sembahlah Allah (saja) dan jauhilah Thaghut”...”, (QS al-Nahl/16: 36).

Berkaitan dengan keimanan kepada para nabi dan rasul ini, Sayid Sabiq menjelaskan, bahwa tidak dibenarkan jika mengimani mereka hanya pada sebagian mereka. Mereka merupakan satukesatuan yang tidak dibeda-bedakan oleh Allah. Mereka semua telah sampai pada puncak keluhuran, ketinggian rohaniah, dan hubungan yang amat erat dengan Tuhan (Usman, 2002). Dan menurut alMaraghi, keimanan terhadap kesatuan kenabian tersebut karena pada dasarnya inti ajaran mereka adalah sama, yakni agama hanif (condong kepada kebenaran) yang berciri khas tauhid. Keimanan secara global ini membawa pada sikap netral terhadap kemungkinan terjadinya perubahan ataupun penyelewengan atas suatu ajaran agama, sehingga terjadi perbedaan ajaran antara satu agama dengan agama yang lain, terutama pada hal-hal yang bukan prinsip. Itu merupakan tanggung jawab mereka terhadap masing-masing Tuhannya (Usman, 2002: 72).

\section{Kesatuan Pesan Ketuhanan}

Al-Qur'an jelas memandang dirinya sebagai mata rantai kritis dalam pengalaman pewahyuan umat manusia. Secara khusus, Islam juga memiliki etos biblical Yahudi dan Kristen, dan Islam memiliki sikap luar biasa inklusif terhadap mereka, yang dengan mereka Islam terhubungkan dengan manusia pertama di bumi (Sachedina, 2002). Begitu juga ke-inklusif-an tersebut diperlihatkan kepada agama-agama di luar keluarga Ibrahim. Karena itu risalah-risalah Tuhan dalam al-Qur'an pun bersifat universal dan berlaku untuk semua manusia, sebagaimana pula halnya dengan risalah-risalah yang disampaikan kepada para nabi dan rasul sebelumnya.

Dalam kajian Budhi Munawar-Rachman, diistilahkan dengan pesan keagamaan atau pesan dasar (risalah al-asasiyyah) Islam, yang pada pokoknya meliputi: perjanjian dengan Allah ('ahd, 'aqd, mitsaq), sikap pasrah kepada Allah (islam), dan kesadaran akan kehadiran Allah dalam hidup (taqwa, rabbaniyyah) (Munawar-Rachman, 1999:143). Dalam al-Qur'an ada penegasan bahwa pesan Tuhan adalah sama, baik untuk umat Nabi Muhammad S.A.W. dan mereka yang menerima Kitab Suci sebelumnya, yaitu, pesan untuk bertaqwa kepada Allah, yaitu :

“... Dan sesungguhnya Kami telah memerintahkan kepada orang-orang yang diberi Kitab sebelum kamu dan (juga) kepada kamu; bertakwalah kepada Allah ...”. (QS al-Nisa’/4: 31)

Ayat ini menurut analisis al-Zuhaili bertujuan untuk mendeskripsikan keberadaan wahyu Allah sejak awal kepada semua pemeluk agama, agar mereka mau berjuang dan beramal saleh (bertakwa) (Wahbah al-Zuhaili, dalam Usman, 2002). Kepatuhan umat beragama terhadap Tuhannya atau disebut juga dengan takwa, dalam maknanya yang bulat hanya bisa dipahami sebagai kesadaran Ketuhanan (God-consciousness) dalam hidup ini, sehingga senantiasa terdorong untuk melakukan kebaikan di setiap saat (Madjid, 1995). Kesadaran Ketuhanan tersbut menurut Fazlur Rahman, erat hubungannya dengan pertanggungjawaban manusia dalam memainkan peranan fungsional religio- 
moral tak mungkin hanya sebagai postulat-postulat intelektual yang harus diimani, tetapi yang lebih penting diamalkan (Rahman, 1985).

Pesan ketakwaan seperti yang diuraikan di atas, pada prinsipnya sama untuk semua umat beragama. Sehingga pesan kepada takwa ini dalam pandangan agama Islam, bersifat universal. Di sinilah dalam argumen keuniversalan pesan keagamaan tersebut, memunculkan arti kesamaan hakikat semua pesan Tuhan. Nmaun arti "kesamaan Agama” di sini bukan kesamaan dalam arti formal dalam aturan-aturan positif yang sering diacu sebagai istilah agama Islam syari'ah, bahkan tidak juga dalam pokok-pokok keyakinan tertentu.

Pengertian "kesamaan" di sini adalah kesamaan dalam hal yang di atas disebut "pesan dasar" al-Qur'an menyebutnya dengan kata "washiyah", yaitu - seperti distilahkan - "ajakan untuk menemukan dasar-dasar kepercayaan” yaitu sikap yang hanif, atau lengkapnya al-hanifiyat al-samhah yang arti literalnya "semangat kebenaran yang toleran" (Munawwar-Rachman, 2001:20-21). Seperti dikatakan hadist berikut:

Ibn Abbas menuturkan bahwa Nabi S.A.W. ditanya, "Agama mana yang paling dicintai Allah?" Nabi menjawab, "Semangat kebenaran yang toleran (al-hanifiyat al-samhah)." (HR Ahmad)

“Aisyah menuturkan bahwa Rasulullah s.a.w. bersabda, ”Hari ini pastilah kaum Yahudi tahu bahwa dalam agama kita ada kelapangan. Sesungguhnya aku ini diutus dengan semangat kebenaran yang toleran (al-hanifiyat al-samhah).” (HR Ahmad).

Nurcholish Madjid menjelaskan bahwa hanif adalah sikap alami manusia yang memihak kepada yang baik dan benar, sebagai kelanjutan dari fitrahnya yang suci bersih (Madjid, dalam Edy A.effendy, 1999). Sikap hidup yang hanif ini yang dalam bahasa teologi Islam justru termuat dalam ajaran tauhid. Ajaran lain menyangkut titik persamaan tersebut - setelah tauhid - misalnya dikatakan oleh QS al-An'am/6: 151-153.

Pemaknaan yang mendasar semacam ini sejajar dengan pengertian Rabbaniyah yang meliputi sikap pribadi yang secara serius berusaha memahami Tuhan dan mentaati-Nya. Oleh karena itu, para nabi dan rasul selalu membawa pesan-pesan moral dan bertujuan membentuk budi pekerti yang luhur guna terwujudnya masyarakat yang baik, sejahtera lahir dan batin.

\section{Sejarah dan Perkembangan Islam Inklusif}

Berdasarkan kerangka doctrinal Islam yang dikemukakan, kaum Muslim mengimplementasikan teologi inklusif sepanjang sejarah Islam. Hijrahnya para sahabat Nabi Muhammaad S. A. W. ke Habasyah (Ethopia) merupakan titik awal pertemuan dan kerja sama kaum Muslimin dengan Ahli Kitab (khususnya Nasrani). Nabi Muhammad S. A. W. memerintahkan para sahabatnya untuk berhijrah ke Habasyah, karena Nabi Muhammad S. A. W. mengetahui bahwa Raja Negus dan rakyatnya adalah para pengikut setia Isa al-Masih. Hal tersebut tidak akan pernah dilakukan oleh Nabi Muhammad S. A. W., jika saja para penganut Nashrani di sana berada jauh dari jalan kebenaran, bahkan hubungan baik tersebut diperkuat oleh Nabi Muhammad S.A.W. sendiri dan para sahabatnya dengan melakukan shalat ghaib ketika mendengar Raja Negus meninggal dunia.

Hubungan seperti itu pun kemudian diperkokoh kembali ketika Nabi Muhammad SAW dan para sahabatnya berhijrah ke Madinah pada 622 M. Pembentukan negara-kota Madinah, yang terdiri dari berbagai etnis dan agama, ini merupakan momen historis sejauh menyangkut implementasi kerangka teologi, doktrin, dan gagasan kerukunan keagamaan Islam terhadap para penganut agamaagama lain, dalam konteks ini, khususnya agama Yahudi dan Nashrani. Pada dataran struktural dan politik, Nabi Muhammad S. A. W. berusaha mencari titik temu dengan berbagai golongan di Madinah 
dengan terlebih dahulu mengakui eksistensi masing-masing kelompok dengan dokumen yang terkenal sebagai “Konstitusi Madinah”.

Begitu juga, seperangkat contoh toleransi keagamaan yang diperlihatkan oleh Khulafa alRasyidin kepada para pengikut agama samawi. Sebagaimana Rasul telah memberikan jaminan kepada umat Kristen Najran bahwa lembaga keagamaan mereka akan dilindungi, dan beliau telah mengeluarkan perintah kepada panglima ekspedisi ke Yaman untuk tidak mengganggu orang Yahudi karena agamanya. Demikian pula para khalifah telah memberikan kepada panglima militer petunjukpetunjuk yang serupa tentang prilaku para serdadu dalam perang. Para panglima yang sukses ini telah mengikuti jejak Nabi Muhammad S. A. W. dalam mengadakan berbagai perjanjian dengan bangsabangsa yang ditaklukan. Berkat perjanjian tersebut, bangsa-bangsa ini telah diberikan kebebasan memeluk agama semula dan tradisi warisan lama dengan syarat agar yang tidak memeluk agama Islam membayar pajak (jizyah) untuk pemerintah. Walaupun pajak ini jauh lebih berat jika dibandingkan dengan pajak yang harus diberikan oleh kaum Muslimin sendiri kepada pemerintahnya. Namun, untuk ukuran zamannya hal itu relatif lebih adil, karena itu terjadi di tengah-tengah dunia driskriminatif yang sangat parah dan kronis. Dan sebagai imbalan, bangsa-bangsa ini (dikenal dengan sebutan ahl al-dzimmah) diberikan perlindungan yang tidak berbeda sedikitpun dengan yang diperoleh dengan kaum Muslim. Oleh karena tindakan-tindakan Nabi Muhammad S. A. W. dan Khulafa' al-Rasyidin yang bijaksana telah menjadi undang-undang yang dipatuhi oleh umat Islam pada masa-masa berikutnya, maka tidaklah berlebihan jika Laura Veccia Vaglieri menyatakan bahwa Islam tidak hanya sekedar berdakwah untuk hidup toleransi (tasamuh) dalam agama, bahwa lebih dari itu, ia menjadikan sikap tasamuh tersebut bagian dari syariat Islam (Vaglieri, 1983: 18-19).

Ketika masa Umar ibn Khaththab meneruskan Sunnah Nabi Muhammad S.A.W. tersebut, terlihat dalam sikapnya terhadap penduduk Yerusalem. Setelah angkatan bersenjata Muslim menaklukan kota Yerusalem, dan kemudian Umar ibn al-Khaththab menerima kunci kota tersebut dari Uskup Agung, dia mengumumkan penandatangan sebuah dokumen perjanjian kebebasan beragama, yang kemudian dikenal dengan sebutan "Piagam Aelia” (karena saat itu Yerusalem dikenal dengan nama Aelia), dalam piagam tersebut antara lain dinyatakan:

"Dengan nama Allah Yang Maha Pengasih lagi Maha Penyayang. Perjanjian ini diberikan oleh Umar, hamba Allah, dan Amir al-Mu'minin, kepada penduduk Aelia. Dia (Umar) menjamin keamanan jiwa dan harta mereka; gereja-gereja, dan salib-salib mereka tidaklah akan dijarah maupun dihancurkan ... atau harta benda dikurangi dalam bentuk apapun. Mereka (pemeluk Kristen) tidaklah akan dipaksa dalam bentuk apapun dalam kaitan dengan agama mereka; dan haruslah mereka terpelihara dari bahaya. Dan tidak akan ada orang Yahudi hidup di tengah mereka ...”

Kaum Muslimin hampir tidak pernah mengadakan perjanjian dengan bangsa-bangsa tanpa dibiarkannya mereka bebas beragama dan tidak menerima sesuatu paksaan dari manapun untuk masuk ke dalam agama baru. Tentara Islam tidak pernah mengikutsertakan rombongan para juru dakwah yang memaksa dan tidak pernah menempatkan mereka pada kedudukan istimewa untuk agar mereka menyebarluaskan atau mempertahankan akidahnya. Malah bukan itu saja, tetapi pada suatu masa, umat Islam pernah menetapkan kewajiban bagi orang yang ingin masuk Islam untuk menempuh suatu cara yang sudah tidak tentu membantu tersiarnya Islam dengan mudah, yakni mereka meminta kepada orang-orang yang akan masuk Islam agar duduk bersimpuh di hadapan hakim seraya menyatakan keinginannya masuk Islam bukan akibat dari suatu tekanan dan bermaksud di balik itu untuk mendapatkan keuntungan duniawi.

Pada hakikatnya orang Yahudi dan Nashrani tidak saja diberikan kebebasan beragama, tetapi juga diberikan hak untuk menduduki jabatan pemerintah, ketika keahlian dan keterampilan pribadi telah menarik perhatian para penguasa. Adapun beberapa keterbatasan yang diperlakukan kepada orang-orang Yahudi dan Nashrani sekitar kebebasan beragama dan beberapa peraturan lain yang 
mengharuskan mereka membawa pita-pita tertentu untuk membedakan dengan orang-orang lain serta larangan membangun geraja-gereja yang baru atau mempletur gereja-gereja lama, maka itu semua terjadi pada masa-masa terakhir, yakni ketika Islam mengenal sikap ekstrim dalam beribadat yang dimasukan oleh bangsa-bangsa 'Ajam (bukan Arab).

Keteladanan Nabi Muhammad S. A. W. yang kemudian dilanjutkan oleh para Khulafa' alRasyidin, juga dipertahankan oleh para khalifah Islam sesudahnya. Para khalifah Bani Abbasiah di Baghdad, misalnya tidak ragu-ragu lagi untuk menjadikan para penganut non Muslim sebagai pejabatpejabat pemerintah, bahkan di antara meraka banyak yang menjadi penterjemah karya-karya ilmuan Yunani maupun Persia yang mendapat jaminan langsung dari pemerintah Abbasiah. Begitu juga dengan para khalifah Umawi di Andalusia (Spanyol), juga dengan konsisten menjalankan politik kemajemukan yang begitu mengesankan. Hal ini dilukiskan oleh Max Dimont sebagai rahmat yang mengakhiri kezaliman keagamaan Kristen.

\begin{abstract}
"Penaklukan Spanyol oleh Bangsa Arab pada tahun 711 telah mengakhiri pemindahan agama kaum Yahudi ke Kristen secara paksa yang telah dimulai oleh Raja Recared pada abad keenam. Di bawah kekuasaan kaum Muslim selama 500 tahun setelah itu, muncul Spanyol untuk tiga agama dan "satu tempat tidur". Kaum Muslim, Kristen, dan Yahudi bersama-sama menyertai satu peradaban yang cemerlang, suatu pencampuran yang mempengaruhi "garis darah” justru lebih banyak daripada mempengaruhi afiliasi keagamaan” (Max I. Dimont, dalam Madjid, 1992: lxxvii).
\end{abstract}

Pengalaman yang hampir sama juga dikembangkan Islam ketika kaum Muslimin melakukan ekspansi sejak tahun 14 H./636 M. ke Persia dan sejak 91 H./711 M. ke wilayah Anak Benua India. Para penganut agama Zoroaster, Hindu, dan Budha diberikan hak-hak yang sama seperti yang telah diberikan kepada kaum Yahudi dan Kristen. Meskipun kepercayaan dan ritual mereka berbeda jauh dengan ajaran tauhid Islam, mereka dibiarkan beribadat sesuai dengan ajaran dan kepercayaan agama masing-masing.

Mengenai agama-agama Persia, selama tiga atau empat abad ketika Islam secara lambat laun menjadi agama yang dominan di sana, terjadi kontak antara Islam dengan agama-agama Persia, khususnya agama Zoroaster dan Mani. Menurut Sayyid Husein Nasr, sejak awal Zoroaster diterima sebagai Ahli Kitab, dan ajaran Islam banyak mempengaruhi pengarang-pengarang Zoroaster, begitu juga sebaliknya.

Sementara agama Mani ditentang dasar-dasar teologinya, namun pengaruhnya dapat dilihat pada kosmologi Ismailiyah, karya-karya Muhamad ibn Zakariya al-Razi, Ibn al-Nadhim, dan alBiruni. Agama Zoroaster, tegas Sayyid Husein Nasr, walaupun diketahui popular dalam segala tingkatannya di mana-mana, tidak banyak dikaji di belahan dunia Islam terutama Arab, tidak seperti halnya di Persia yang merupakan negeri asal agama ini (Nasr, 2000). Pengaruh agama Zoroaster ini dapat dilihat dari karya-karya seperti penyair sufi Hafid, Shihabuddin Suhrawardi, Mulla Shadra, dan lainnya.

Untuk India, kaum Muslim di sana banyak yang menanamkan toleransi terhadap tradisi setempat. Sekalipun Islam secara kultural dominan di sana (Dinasti Mughol India), namun Hinduisme tetap hidup dan berkembang. Selain dari kebijakan Dinasti Mughal yang mengembangkan pluralitas agama, menurut Karen Amstrong, adalah karena bentuk Hinduisme yang paling kreatif, yaitu menekankan tentang kesatuan aspirasi agama: semua jalan adalah sah, selama masing-masing mengutamakan cinta batin kepada Tuhan Yang Maha Esa (Amstrong, 2002). Ini jelas selaras dengan paham Islam paling dominan di India, yaitu sufisme dan filsafat. Abdul Karim Shahratsani, seorang ahli perbandingan agama abad ke-12, juga mengakui bangsa India adalah sebuah bangsa dan komunitas (agama) yang besar (ummat al-kabirah wa millat al-‘adzimah), namun mereka memiliki 
pandangan dan ideologi yang berbeda (Engineer, 1999). Mereka bukanlah termasuk katagori kafir, walaupun para ulama tidak sepakat mereka sebagai Ahli Kitab, ungkap Engineer (1999).

Tidak hanya kaum terpelajar Islam di India sejak masa Dinasti Mughal menyebut menyebut pemeluk agama hindu sebagai Ahli Kitab, memiliki silsilah nabi-nabi sebelum datangnya nabi Islam dan bermula dengan Nabi Adam A. S., namun juga beberapa komentator Muslim India menyatakan bahwa Nabi Zulkifli (QS al-Anbiya'/21: 85). Al-Qur'an menjelaskan: "Dan (ingatlah kisah) Ismail, Idris, dan Dzulkifli. Semua mereka termasuk orang-orang yang sabar." (QS al-Anbiya'/21:85). Dzulkifli yang dimaksudkan daalam ayat ini adalah Budha dari Kifl (Kapilawastu) dan "pohon aras" yang disebut dalam QS al-Thin/95:1. Al-Qur' an menjelaskan: "Demi (buah) Thin dan (buah) Zaitun." (QS al-Thin/95: 1). Buah Thin yang dimaksudkan dalam ayat ini adalah pohon bodhi yang di bawahnya Budha memperoleh pencerahan atau illuminasi (Nasr, 2000).

Kawasan anak benua ini telah sejak lama terbebas dari intoleransi agama, dan selama abad keempat belas dan kelima belas kaum Muslim dan Hindu menjalin kerjasama di bidang seni dan proyek-proyek intelektual. Beberapa orang Muslim dan Hindu membentuk kelompok masyarakat antariman, yang paling penting di antaranya menjadi Sikhisme, didirikan oleh Guru Namak pada abad kelima belas. Bentuk baru monoteisme ini berkeyakinan bahwa Allah identik dengan Tuhan Hinduisme. Dari pihak Muslim, pakar Iran, Mir Abu Al-Qasim Findiriski (w.1641), mengajarkan karya-karya Ibn Sina di Isfahan dan juga menghabiskan cukup banyak waktu untuk mempelajari Hinduisme dan Yoga (Amstrong, 2002).

Pada masa pemerintahan Akbar I, Kaisar Mughal III yang berkuasa pada tahun 1560-1605. Kehidupan pribadi Akbar diabadikan oleh Abulfazl Allami (1551-1602) di dalam bukunya, Akbar Namah (Kitab tentang Akbar). Selama hidupnya Akbar berupaya menerapkan prinsip-prinsip sufisme ke dalam sejarah peradaban. Pada masa ini semangat toleransi dan kerja sama ini paling jelas dibuktikan dalam berbagai kebijakan, seperti pada 1575, Akbar mendirikan Rumah Ibadah, tempat para ahli dari semua agama berkumpul mendiskusikan masalah ketuhanan. Bahkan Akbar membuat kebijakan yang sangat radikal, yaitu mendirikan tarikat sufinya sendiri, yang mendedikasikan diri pada "monoteisme ketuhanan" (tauhid al-Ilah), kepercayaan radikal akan Keesaan Tuhan yang mewahyukan diri-Nya pada tiap agama (Yatim, 2002).

Penghormatan terhadap semua agama mengakibatkan Akbar rela mengorbankan kesenangankesenangan pribadinya. Dari catatan Karen Amstrong, dijelaskan bahwa Akbar memperlihatkan beberapa sikap yang sangat menakjubkan; karena kepekaannya terhadap orang Hindu, dia menjadi seorang vegetarian, meninggalkan kegiatan berburu binatang - olahraga yang sangat digemarinya dan melarang menyembelih hewan kurban di hari ulang tahunnya atau di tempat-tempat suci orang Hindu (Yatim, 1998: 346; Dewan Redaksi Ensiklopedi Islam, 1994: 221, Jil. 2).

Allami memandang Akbar sebagai penguasa ideal menurut falsafah dan manusia sempurna pada masanya. Peradaban dapat membawa pada perdamaian universal jika masyarakat yang baik dan liberal berhasil diciptakan oleh penguasa semacam Akbar yang telah membuat fanatisme menjadi mustahil. Islam dalam pengertian asalnya, yakni sikap tunduk kepada Tuhan, bisa dicapai oleh agama apapun: yang sering disebut dengan agama Muhammad tidak memiliki monopoli atas Tuhan (Yatim, 1998). Sebagai hasil dari inklusivitas Islam tersebut, masih dapat disaksikan sampai saat ini bahwa penduduk Anak Benua India mayoritas masih memeluk agama Hindu. 


\section{SIMPULAN}

Dengan mengikuti uraian tersebut terlihat bahwa ajaran Islam menjunjung tinggi adanya paham keagamaan yang bersifat inklusif-pluralis yang ditandai dengan adanya dialog dan kerja sama serta perasaan kemanusiaan. Cara beragama yang demikianlah yang akan menimbulkan ketentraman, keharmonisan, kedamaian, dan ketahanan. Untuk mewujudkan hal ini perlu dilakukkan kritik teks (hermenetik) terhadap tafsiran para ulama pada teks ayat-ayat suci dalam kitab, serta dengan menghilangkn unsur-unsur perbedaan dan mengedepankan unsur-unsur persamaan. Selain itu hal-hal yang selama ini ada dalam sejarah yang dapat menghambat terjadinya hubungan yang harmonis antaragama juga harus dihilangkan, yaitu persoalan yang bersifat politis, ideologis, orientalis, misionaris, dan sebagainya. Untuk melakukan hal ini diperlukan adanya keberanian, ketulusan, kerelaan, dan pandangan jauh ke depan.

Dalam konteks keanekaragaman sikap yang paling mendasar untuk menerima kebhinekaan adalah keterbukaan menerima berbagai kemungkinan dan perbedaan. Dalam sikap keterbukaan ada kemauan menerima bahwa ada yang lain, yang berbeda. Yang jelas mental attitude fundamentalis yang tertutup berbanding terbalik dengan situasi keanekaragaman yang menuntut keterbukaan. Dengan demikian, fundamentalisme sangat potensial menjadi kekuatan yang disintegratif, bahkan pada titik yang ekstrim dapat bersifat sangat destruktif.

Jalan keluar untuk mengantisipasi situasi itu dapat dimulai dari pihak masyarakat agama sebagai agent of change. Yang perlu dilakukan oleh pihak agama-agama adalah mencari dan menemukan celah-celah integrative, dengan meredusir, seminimal mungkin kekuatan dis-integratif yang ada di dalamnya, tanpa harus mengabaikan penghayatan terhadap agama masing-masing. Jika ini berhasil, maka minimal perkembangan fundamentalisme dalam agama-agama dapat diatasi, sekurangkurangnya ditekan. Di sinilah pemahaman keagamaan yang inklusif dan pluralis jelas sekali diperlukan untuk mengantisipasi situasi tersebut. Begitu pula halnya dengan pemahaman Islam inkluusif.

Walaupun memang kehadiran agama sebagaimana diakui oleh Jose Casanova selalu disertai dengan "dua muka" (jenus face). Pada satu sisi, secara inherent agama memiliki identitas yang bersifat "exclusive", "particularist", dan "primordial". Di sisi lain, agama juga kaya akan identitas yang bersifat "inclusive”, universalist", dan trancending” (Effendy, 2001: 7-8, 23). Namun, kalam konteks keindonesiaan yang serba plural, khususnya dalam hubungan antarumat agama, identitas yang pertama tidak perlu ditonjolkan secara berlebih-lebihan. Karena berlebih-lebihan dalam hal itu akan memicu fundamentalisme semakin menjadi-jadi. Justru, identitas yang kedualah yang perlu mendapat perhatian.

Islam di Indonesia merupakan agama mayoritas yang dianut oleh berbagai kalangan penduduk, sehingga keberadaannya sangat menetukan masa depan bangsa. Tidaklah berlebihan jika dikatakan, "di pundak merekalah tanggung jawab kemajuan bangsa ini”. Jika bangsa ini maju, berarti menunjukkan keberhasilan Islam, dan jika bangsa ini mundur, berarti menunjukkan kegagalan Islam. Singkat kata Islam di Indonesia sedang dipertaruhkan.

Di sini perlu ditegaskan kembali, bahwa konsep Islam Inklusif, sama sekali tidak menghendaki usaha penyatuan agama atau mencampur adukannya. Konsep ini justru menghendaki setiap pemeluk agama konsekuen dengan ajaran agama yang diyakininya. Akan tetapi, kesungguhan beragama tersebut tidak boleh disertai dengan anggapan bahwa agama lain sepenuhnya salah. Setiap ajaran agama pasti mengandung nilai-nilai kebenaran. Dan bagi kaum Muslim, selama nilai-nilai tersebut tidak bertentangan dengan al-Qur'an harus mengakui dan menerimanya sebagai kebenaran. 
Jika tidak sesuai dengan yang diharapkan, perbedaan tersebut sebagai rahmat dari Tuhan Yang Maha Esa, begitu pula terhadap nilai-nilai di luar agama.

Adapun kebenaran yang bersifat esensial, absolut, universal, dan metahistoris, ada pada common platform (titik temu) yang sungguh-sumgguh dan akan dicapai. Dalam bahasa al-Qur'an disebut dengan istilah kalimatun sawa' (suatu kata/ketetapan yang sama). Dalam pandangan seorang sufi kontroversial, al-Hallaj, pada dasarnya agama-agama itu memiliki Tuhan yang sama, yaitu Allah, Tuhan Yang Maha Esa (Usman, 2002). Itulah titik temunya. Keyakinan ini dikuatkan oleh firman Allah SWT dalam al-Qur'an surat al-Ankabut/29 ayat 46 dan Alu 'Imran/3 ayat 6).

"Dan katakanlah: "Kami telah beriman kepada (kitab-kitab) yang diturunkan kepada kami dan yang diturunkan kepadamu. Tuhan kami dan Tuhanmu adalah satu, dan hanya kepadaNya kami berserah diri”. (QS al-Ankabut/29: 46)

Katakanlah: "Hai Ahli Kitab, marilah (berpegang) kepada suatu kalimat (ketetapan) yang tidak ada perselisihan antara kami dan kamu, bahwa tidak kita sembah kecuali Allah dan tidak kita persekutukan Dia dengan sesuatupun, dan tidak (pula) sebagian kita menjadikan sebagian yang lain sebagai Tuhan selain Allah”. Jika mereka berpaling maka katakanlah kepada mereka: "Saksikanlah, bahwa kami adalah orang-orang yang berserah diri (kepada Allah)”. (QS Alu 'Imran/3: 64)

Adanya perintah al-Qur'an untuk mencari titik temu itu berarti umat Islam seharusnya bersikap lapang dada dan terbuka, tidak eksklusif apalagi ekstrim. Karena perbedaan pandangan, keyakinan, dan bahkan agama merupakan order of nature atau sunnatullah yang tak terelakkkan. Bahkan dalam Islam, Tuhan mengakui keabsahan agama-gama lain, sebagaimana dijelaskan oleh Kitab Suci. Al-Qur'an menjelaskan:

"Jikalau Tuhan menghendaki, tentu Dia menjadikan manusia ummat yang satu, tetapi mereka senantiasa berselisih pendapat”. (QS Hud/11: 118). “... Untuk tiap-tiap ummat di antara kamu, Kami berikan aturan dan jalan yang terang. Sekiranya Allah menghendaki, niscaya kamu dijadikan-Nya satu ummat (saja), tetapi Allah hendak menguju kamu terhadap pemberiannya kepadamu ...". (QS al-Ma'idah/5: 48).

"Sesungguhnya orang-orang Mu'min, orang-orang Yahudi, orang-orang Nashrani, dan orang-orang Shabi'in, siapa saja di antara mereka yang benar-benar beriman kepada Allah, Hari Kemudian, dan beramal shaleh, mereka akan menerima pahala dari Tuhan mereka, tidak ada kekhawatiran terhadap mereka, dan tidak (pula) mereka bersedih hati." (QS alBaqarah/2: 62). "Sesungguhnya orang-orang Mu'min, orang-orang Yahudi, orang-orang Shabi'in, dan orang-orang Nashrani, siapa saja (di antara mereka) yang benar-benar beriman kepada Allah, Hari Kemudian, dan beramal shaleh, maka tidak ada kekhawatiran terhadap mereka, dan tidak (pula) mereka bersedih hati.” (QS al-Ma'idah/5: 69).

Karena itu, dalam perspektif filsafat perennial - yang dalam bahasa Latinnya disebut philosophia perennis -, ialah sebuah filsafat, yang dipandang bisa menjelaskan segala kejadian yang bersifat hakiki, menyangkut kearifan yang diperlukan dalam menjalankan hidup yang benar, yang rupanya hakikat dari seluruh agama-agama dan tradisi-tradisi besar spiritualitas manusia. Filsafat ini sangat penting, karena hanya dengan filsafat inilah, kita bisa memahami kompleksitas perbedaanperbedaan yang ada, antara satu dan lain tradisi plus agama, yang selama ini dianggap banyak orang, bahkan oleh para ahli agama sekalipun, bahwa "yang ada dalam realitas agama-agama hanyalah perbedaan-perbedaannya saja” (Munawar-Rahman, 2001:79).

Misalnya, agama Hindu dan Islam adalah dua agama yang berbeda sama sekali. Secara otomatis, tidak ada satu point pun yang mempertemukan antara keduanya, apalagi - begitu katanya dua agama ini mempunyai sejarah bentukan sosial yang berbeda. Padahal, kedua agama ini, seperti 
dikatakan oleh kaum perennialis, pada tingkat the common vision - sesuai istilah Huston Smith mempunyai kesatuan, kalau tidak malah kesamaan gagasan dasar yang dalam Islam disebut dengan "pesan dasar agama". Yakni Islam yang makna generiknya berarti "sikap pasrah", untuk selalu bertakwa yang dihayati sebagai makna kehadiran Tuhan (omnipresent) dalam kehidupan sehari-hari.

Dalam konteks agama-agama, penerimaan adanya the common vision ini, berarti menghidupkan kembali the many, yang dalam hal ini adalah realitas eksoteris agama-agama, kepada asalnya, The One, yang diberi berbagai macam nama oleh para pemeluknya sejalan dengan perkembangan kebudayaan dan kesadaran sosial serta spiritual manusia. Sehingga, kesan empiris tentang adanya agama-agama yang majemuk itu, tidak hanya berhenti sebagai fenomena factual an sich, tetapi juga dilanjutkan bahwa: "ada satu realitas yang menjadi pengikat yang sama” dari agamaagama tersebut, yang dalam bahasa simbolis disebut "Agama itu” (the Religion). Agama (the Religion) dalam konteks inilah yang bisa menjadi - istilah Huston Smith - the common vision of the world's religions, atau istilah yang begitu disukai oleh penganut filsafat perennial adalah the transcendent unity of religion (kesatuan transenden agama-agama), yang merupakan mainstream penting dalam filsafat perennial (Munawar-Rahman, 2001; Schuon, 2003).

Konsep keanekaragaman agama, diharapkan mampu menjadi landasan etis bagi kehidupan umat beragama di dunia, khususnya di Indonesia yang kondisinya serba majemuk ini. Karena pada dasarnya dalam tataran etis inilah, berbagai agama di dunia ini banyak memiliki kesamaan tentang prinsip-prinsip kebaikan maupun keburukan. Maka menurut John Hick, walaupun ajaran moral dari tradisi besar selalu "diselimuti" oleh sejarah lokasi yang khusus, dilatarbelakangi oleh konteks keberadaan masyarakatnya dan sebagainya, akan tetapi ada golden rule - dalam hal positif ataupun negatif - bahwa prinsip-prinsip nilai tersebut luas, yakni yang baik adalah bermanfaat bagi orang lain, sementara yang buruk berarti menyakiti mereka. Prinsip-prinsip moral dalam tradisi besar semacam cinta, kasih, murah hati, belas kasih selalu menjadi faktor yang mendasar dalam pengakuan seseorang sebagai mediator yang otentik dari kebenaran ... where we find the ethical of transformation of human existence from self centeredness to reality centeredness (Usman, 2002: 132-133). Oleh karena itu, tak ada alasan bagi umat beragama untuk saling menyakiti karena pada dasarnya mereka memiliki platform yang sama.

Justru ajakan melakukan perlombaan dalam kebaikan (fastabiq al-khairat) dalam QS alAn'am/6: 48, adalah tantangan positif yang memperoleh tanggapan yang baik dari kalangan umat beragama. 'Perlombaan' dalam kebaikan tersebut bisa berupa dialog, kerja sama, komitmen bersama, dan sebagainya.

\section{DAFTAR PUSTAKA}

Abi Thalib, A. (1991). Al-Mukhtar min Nahj al-Balaghah. Cetakan ke-1. Muhammad al-Baqir (ed.). Bandung: Mizan.

Ali, M. M. (1980). Islamologi (Dinul Islam). Jakarta: Ikhtiar Baru van Hoeve.

Amstrong, K. (2002). Sejarah Tuhan, Kisah Pencarian Tuhan yang Dilakukan oleh Orang-orang Yahudi, Kristen, dan Islam Selama 4.000 Tahun. Cet. ke-4. Zainul Am (penterj.). Bandung: Mizan.

Asfour, G. (1998, 21 September). Islam Sungai Vs Islam Gurun. dalam Umat, No. 11 Tahun. 4, 21 September 1998. 
Azra, A. (1999). Konteks Berteologi di Indonesia Pengalaman Islam. Cetakan ke-1. Jakarta: Paramadina.

Departemen Agama Republik Indonesia. (2001). al-Qur'an dan Terjemahnya. Madinah: al-Mujamma' Khadim al-Haramain asy-Syarifain al-Malik Fahd li Thiba’at -Mushhaf asy-Syarif.

Dewan RedaksI EnsIklopedI Islam. (1994). Ensiklopedi Islam. Jilid II, Cetakan ke-3. Jakarta: Ichtiar Baru van Hoeve.

Echols, J. M. dan Shadily, H. Kamus Inggris Indonesia. Cetakan ke-23. Jakarta: Gramedia.

Effendy, B. (2001). Masyarakat Agama dan Pluralisme Keagamaan, Perbincangan Mengenai Islam, Masyarakat Madani, dan Etos Kewirausahaan. Cetakan ke-1. Yogyakarta: Galang Press.

Engineer, A. A. (1999). Islam dan Teologi Pembebasan. Cetakan ke-1. Agung Prihantoro (penterj.). Yogyakarta: Pustaka Pelajar.

Hamka, B. (1989). Pelajaran Agama Islam. Cetakan ke-10. Jakarta: Bulan Bintang. . (1986). Iman dan Amal Shaleh. Cetakan ke-3. Jakarta: Pustaka Panjimas.

Hidayat, R. T. (1990). Khazanah Istilah al-Qur'an. Cetakan ke-2. Bandung: Mizan.

Jalil, M. A. (1999). PKB dan Inklusivisme Islam. Marzuki Wahid, dkk. (ed.), Geger di Republik NU, Perebutan Wacana, Tafsir Sejarah, Tafsiran Makna. Jakarta: Kompas.

Madjid, N. (2001). Sekapur Sirih. dalam Sukidi, Teologi Inklusif Cak Nur. Cetakan ke-2. Jakarta: Kompas.

. (1999). Beberapa Renungan Kehidupan Keagamaan untuk Generasi Mendatang. dalam Edy A. Effendy (ed.). Dekontruksi Islam Madzhab Ciputat. Cetakan ke-1. Bandung: Zaman Wacana Mulia.

. (1995). Islam Agama Kemanusiaan, Membangun Tradisi dan Visi Baru Islam Indonesia. Cetakan ke-1. Jakarta: Paramadina.

. (1992). Islam Doktrin dan Peradaban, Sebuah Telaah Kritis tentang Masalah Keimanan, Kemanusiaan, dan Kemodernan. Cetakan ke-1. Jakarta: Paramadina.

Munawar-Rachman, B. (2001). Islam Pluralis, Wacana Kesetaraan Kaum Beriman. Cetakan ke-1. Sukidi (ed.). Jakarta: Paramadina.

. (1999). Resolusi Konflik Agama dan Masalah Klaim Kebenaran. dalam Sandra Kartika dan M. Mahendra (ed.). Dari Keseragaman Menuju Keberagaman, Wacana Multikultural dalam Media. Jakarta: LSPP.

Nasr, S. H. (2004). Taswauf Dulu dan Sekarang (terj.) dari Living Sufism, Abdul Hadi WM (penterj.). Ceatakan ke-4. Jakarta: Pustaka Firdaus.

Nasution, H. (1985). Islam Ditinjau dari Berbagai Aspeknya. Cetakan ke-5. Jakarta: UI Press.

Nata, A. (2001). Peta Keagaman Pemikiran Islam di Indonesia. Edisi ke-1, Cetakan ke-1. Jakarta: Raja Grafindo Persada. 
Rahman, F. (1985). Islam dan Modernitas, tentang Transformasi Intelektual. Ahsin Muhammad (penterj.). Bandung: Pustaka.

. (1983). Tema Pokok al-Qur'an. Anas Mahyuddin (penterj.). Cetakan ke-3. Bandung: Pustaka.

Sachedina, A. A. (2002). Kesetaraan Kaum Beriman, Akar Pluralisme Demokratis dalam Islam. Satrio Wahono (penterj.). Cetakan ke-1. Jakarta: Serambi.

Schoun, F. (2003). Mencari Titik Temu Agama-agama. Saafroedin Bahar (penterj.). Cetakan ke-4. Jakarta: Pustaka Firdaus.

Shihab, A. (1998). Islam Inklusif, Menuju Sikap Terbuka dalam Beragama. Cetakan ke-4. Bandung: Mizan.

Shihab, M. Q. (1998). Wawasan al-Qur'an, Tafsir Maudhu'i atas Pelbagai Persoalan Umat. Cetakan ke-8. Bandung: Mizan.

Sjadzali, M. (1997). Ijtihad Kemanusiaan. Cetakan ke-1. Jakarta: Paramadina.

Smith, H. (2005). Agama-agama Manusia, (terj.) dari The Religion of Man. Safroedin Bahar (penterj.). Jakarta: Yayasan Obor Indonesia.

Sukidi. (2001). Teologi Inklusif Cak Nur. Cetakan ke-2. Jakarta: Kompas.

Suma, M. A. (2001). Pluralisme Agama Menurut al-Qur'an, Telaah Aqidah dan Syari'ah. Cetakan ke1. Jakarta: Pustaka Firdaus.

Suseno, F. M. (2003). Membongkar Kedok Pluralisme, Merayakan Inklusifisme. dalam Majalah Rohani, A. Sudiarja dan A. Bagus Laksana (ed.). Berenang di Arus Zaman, Tantangan Hidup Religius di Indonesia Kini. Cetakan ke-1. Yogyakarta: Kanisius.

Taha, M. M. (1996). The Second Massage of Islam: Syari'ah Demokratik. Nur Rahman (penterj.). Cetakan ke-1. Surabaya: eLSAD.

Usman, F. (2002). Wahdat al-Adyan, Dialog Pluralisme Agama. Cetakan ke-1. Yogyakarta: LKiS.

Vaglieri, L. V. (1983). Apologi Islam terjemahan dari Apologia Dell Islamismo. Cetakan ke-3. Ahmad Daudy (penterj.). Jakarta: Bulan Bintang.

Yatim, B. (2002). Sejarah Peradaban Islam. Cetakan ke-13. Jakarta: Raja Grafindosada. 